\title{
Teachers' and Students' Perceptions of Online Learning Interactions Amidst the COVID-19 Pandemic in Indonesian Senior High Schools
}

Angen Yudho Kisworo' ${ }^{1}$. Oktaviani2

1,2Universitas Dinamika, Surabaya, Indonesia

\begin{tabular}{|c|c|}
\hline (A) Check for updates open $\mathrm{O}$ access (c) & DOI: https://doi.org/10.46245/ijorer.v2i6.166 \\
\hline Sections Info & ABSTRACT \\
\hline Article history: & The research investigates Indonesian high school teachers' and students' \\
\hline Submitted: October 29, 2021 & perceptions of learning interactions when the classroom settings were \\
\hline Final Revised: November 18, 2021 & moved online at the beginning of 2020 . Conducting this research is \\
\hline Accepted: November 19, 2021 & essential to unpack the development of online learning after more than a \\
\hline Published: November 30, 2021 & year of pandemic hits in the world. To unload the issue, this research \\
\hline Keywords: & employed a mixed-method design. A survey questionnaire was shared \\
\hline Interaction & with the teachers around Indonesia, and from this effort, 136 teachers \\
\hline Online learning & and 107 students agreed to participate in this research. Then, two \\
\hline Perceptions & teachers and two students were chosen to explain in detail their online \\
\hline 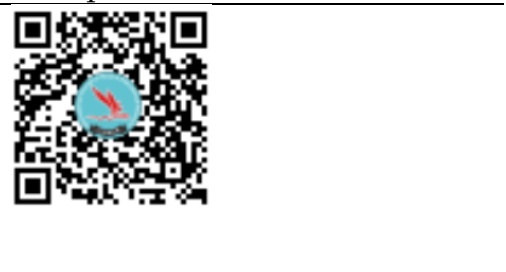 & $\begin{array}{l}\text { learning experience. Based on the results, teachers tend to positively } \\
\text { perceive online learning, while students moderately perceive the } \\
\text { learning. Five interaction aspects influence perceptions: social } \\
\text { interaction, instructional interaction, technology interaction, teachers' } \\
\text { and students' engagement. The findings suggest that teachers should be } \\
\text { more active in enhancing their pedagogical practice and social approach } \\
\text { in online classrooms. }\end{array}$ \\
\hline
\end{tabular}

\section{INTRODUCTION}

In 2020, the COVID-19 pandemic became a starting point for education around the globe to access technology as a part of teaching and learning activities. Due to this circumstance, all governments in the world took significant measures which impose the use of the internet and technology for all learning activities (Chakraborty et al., 2020). In Indonesia, the ministry of education and culture issued a policy that demands all educational institutions to close the door of classrooms and to open online classrooms for the students. The goal of completing the face-to-face classroom was to stop the virus from spread among teachers and students.

Eventually, this pandemic has become the accelerator for digital education transformation for many institutions in the world, including in Indonesia. The extensive lockdown and the use of technology for schools have made distance learning spaces more critical for everyone who wants to pursue an education (Korkmaz and Toraman, 2020). Korkmaz and Toraman (2020) further argue that adapting to this digital learning transformation is necessary because future education will heavily demand technology. Thus, future research should address factors that unpack the effectiveness of online learning so that learning in an online space can become more meaningful for teachers and students (Widiyono, 2020). By understanding online learning issues, digital learning will be more promising and effective for all learners.

Some researchers believe that interactions are the key (Anderson, 2004; Baber, 2020; Mehall, 2020; York \& Richardson, 2012). According to Baber (2020), an effective interaction in online learning will lead to students' knowledge and better learning outcomes. Several studies which delve into this 
These studies show that teachers cannot neglect the interaction they create in an online classroom because it will disadvantage learning in an online space. Notion found that increased interaction creates better learning than learning with less interaction (Baber, 2020; Eom and Ashill, 2016). Ultimately, meaningful interaction is a necessary tool for digitally enhancing the effectiveness of learning (Mehall, 2020).

Currently, most research in Indonesia discussing online learning focuses on challenges on learning through the internet. Nevertheless, although interactions have significant roles in improving the quality of online learning, in the Indonesian context, online learning interactions are still under-researched. For instance, based on several studies, students and teachers admit that lousy internet connection, unsolved technological issues, and lack of knowledge on online pedagogy have become significant issues in the face-to-screen classroom. (Absor, 2020; Annur \& Hermansyah, 2020; Handarini and Wulandari, 2020; Jalal, 2020; Jamilah, 2020; Kurniawan, 2020; Rigianti, 2020; Widiyono, 2020; Wuladari et al., 2020). To delve into online learning issues from a different perspective, this research investigates the effectiveness of online learning through the lens of senior high school students' and teachers' perceptions of online interactions in Indonesia. Focusing on this issue, this research attempts to answer the question. "How are Indonesian senior high school teachers' and students' perceptions of interaction in online classrooms?"

\section{Purposeful Interactions in An Online Learning Classroom}

Interactions are an indispensable part of learning in any context. It means that increasing the quality of interactions will open an opportunity to improve students' learning outcomes and achievements (Baber, 2020). In the online learning context, Roblyer and Wiencke (2003) specifically highlight the importance of interactions. They stated that the online learning environment should cater to supportive and encouraging interactions to ensure positive learning in distance education. Similar to this argument, Anderson (2004) argues that interactions in online classrooms are the fundamental key to conducting distance learning. Interactive interactions often support social presence and strengthen the learning process better (Ally, 2004).

To provide purposeful interaction for students, Mehall (2020) argues that interactions in an online classroom should have three fundamental components: intentional instructional, social, and support interactions. Related to the first component, purposeful instructional interaction is the interaction that directly relates to teaching and learning activities. In other words, the core of interaction is created to cater to students' learning to understand specific knowledge (Northrup et al., 2002). Through this kind of interaction, students can internalize the materials and expertise informed by the teachers (Murray et al., 2012). Thus, in this interaction, students cannot only respond to a straightforward conversation or answer. In this purposeful instructional interaction, the students should deliver complex information or give difficult feedback to peers or teachers (Mehall, 2020).

In addition to complex responses or feedback, teachers also need to promote a collaborative learning atmosphere to enhance instructional interactions. Collaborative learning is required in order to create a space that caters to interactions among students because students will heavily rely on their peers' feedback and thoughts (Wicks et al., 2015). Xhaferi and Xhaferi (2020) suggest that purposeful discussion and cooperation among students will lead to successful teaching. Like this statement, Murray et al. (2012) found and hypothesized that interactions had become a motor of students' 
success in learning the materials. It means that purposeful instructional interactions are crucial to aid students in achieving their learning goals (Murray et al., 2012). Ultimately, teachers should design their interactions with the students properly to achieve the purposes of learning.

Regarding the second component, which is social interaction, teachers need to consider this carefully. A well-executed social interaction between teachers and students aids students in establishing positive online learning experiences (Boling et al., 2012). Consequently, when social interaction does not spotlight the teachers in an online classroom, it creates a barrier that hinders the students from learning new knowledge from the teachers (Boling et al., 2012). Additionally, Lasfeto and Ulfa (2020) specifically address the importance of social interaction in an online classroom. In their research, intense students' interaction aid students to improve the students' self-directed learning. Having high self-directed learning may be beneficial to increase the opportunity to become successful learners in online classrooms (Lasfeto and Ulfa, 2020). As a result, due to social interaction in an online classroom, students tend to perceive the learning process (Horzum, 2015) positively. Ultimately, social interaction among teachers and students is essential for an online classroom's teaching and learning process.

That said, it demonstrates that social presence is a fundamental aspect of social interaction. Garrison et al. (2010) believe that social presence is vital because it is often associated with students' sense of belonging in the online context. Accordingly, to better understand social presence, experts attempt to delineate what social presence is. For example, according to Garrison (2009), social presence is an effort from the learners to "communicate purposefully in a trusting environment and develop an interpersonal relationship by projecting their personalities." This definition reveals that social presence becomes a safe setting for individuals to start purposeful interpersonal interaction in the online classroom (Mehall, 2020). In other words, students cannot integrate into an online classroom properly if teachers do not provide social interaction. It is another reason social presence is crucial in synchronous/asynchronous learning.

Another component that cannot be neglected in online learning is supportive interaction. In this context, supportive interaction is closely related to LMS management (learning management system) (Mehall, 2020). Harris \& Greer (2017) suggest that a well-designed LMS significantly aids students in digesting the materials, especially when the materials are designed to precisely fulfill the students' needs. Al-Busaidi's (2012) study shows that LMS positively supports the learning process if LMS design and structure are considered valuable and accessible. Further, LMS should also address the students`struggle on some crucial aspects of learning. For example, Mehall (2020) suggests that LMS can provide information related to referencing formatting, supportive websites, or software that can add more positive experience to students learning. Thus, the students can comprehensively learn the materials which have been provided and designed in LMS.

\section{Measuring purposeful interaction in an online classroom}

To measure the effectiveness of online interactions between teachers and students in Indonesia's senior high school, this research employs the interactions rubric designed by Roblyer and Wiencke (2003), namely the "rubric of assessing interactive qualities in distance course" (Roblyer and Wiencke, 2004). Mehall (2020) suggests that this rubric is valid to measure learners' perceptions of online learning interactions. Based on Roblyer 
\& Wiencke (2004) explanations, the rubric was evaluated by 42 online instructors to give feedback for the rubric's improvement. Not only were reviewed by instructors but the rubric was also used to measure learners' perceptions across four different courses to check whether the results were consistent.

Furthermore, according to Roblyer \& Wiencke's (2004) study, the rubric was proven to be reliable to measure perceptions of online interactions. To check the rubric's reliability level, Roblyer \& Wiencke (2004) employed the strategy to verify the rubric's interrater reliability level. The rubric's Cronbach's alpha level was calculated, and the results show that the consistency of the rubric is high (Cronbach alpha level of .64 .88. 95. And .93). It means that the rubric is reliable to measure the learners' perceptions. Additionally, Roblyer \& Wiencke (2004) estimate the correlation between rubric scores and course evaluation scores. The correlation scores among rubric elements were significant with subscores at the .01 significance level based on the results. Based on these results, Mehall (2020) recommends the researchers use this rubric to determine the participants' perceptions of interactions in online learning.

Another reason this study employs the rubric created by Roblyer and Wiencke (2004) is the connection between the rubric and the interaction components argued by Mehall (2020). The rubric measures five fundamental aspects of interactions in an online classroom, namely [1] social building interaction, [2] instructional design interaction, [3] technology resources interactivity, [4] learners' engagement, and [5] teachers' engagement in the learning. The five aspects measured in this rubric clearly show that the rubric address three interaction components explained by Mehall (2020)

Rubric for social interaction, for example, directly measures the social presence and social interaction that exist in the online classroom. On the other hand, the instructional design interaction rubric directly addresses the purposeful instructional interaction aspect, which deals with the students' and teachers' interactions in the learning process. The rubric of technology resources activity can be linked to supportive interactions created for LMS. Meanwhile, teachers' and students' engagement can measure both purposeful instructional and support interactions. Ultimately, Mehall (2020) suggests that this rubric can be used as a tool to measure the level of interactions between teachers and students in an online classroom.

The instruments in the rubric are easy to be completed by the participants (Mehall, 2020). Roblyer and Wiencke (2004) stated that the rubric had provided scores for each aspect mentioned earlier. The score is attached to the corresponding description and label, and all participants can choose a perception based on their thoughts. For each interaction aspect, the instruments were labeled with 1 to 5 , with one as the lowest and five as the highest score. If the teachers or students choose a score of 1 in each element, the quality is low. For scores 2 and 3, this means that the quality is minimum and moderate, respectively. If the teachers or students give a score of 4 , it means the interaction quality is above average. Meanwhile, if the score is 5, this means that the quality of the interactions is high.

In addition, to describe the overall quality of interaction in an online classroom, Roblyer \& Wiencke (2004) state that if the total score for all interaction elements is between 1 to 7 , the overall interaction is low. For a score between 10 to 17 , it means that the general interaction is moderate. Further, if the score is between 18 to 25 , the overall interaction in the online classroom is high. 


\section{RESEARCH METHOD \\ General Background}

The research employed an explanatory sequential mixed method design to elicit the data to investigate students' and teachers' perceptions of online learning interaction in Indonesian senior high schools. This method was chosen because it could unveil the issue of perceptions from broader perspectives and understand the value of a phenomenon (Creswell \& Clark, 2017). Further, according to them, this research design also provides a complete picture of the issue being studied. In conducting the research, the researchers conducted a survey and semi-structured interviews with students and teachers. The survey's goal was to gather various perceptions from the participants across Indonesian senior high schools to address the research question. Further, the researchers conducted the semi-structured interview because deeper insights regarding teachers' and students' perceptions were needed to delve into the issues in online learning amidst the pandemic. In addition, the detailed process of explanatory sequential mixed method design can be seen in Figure 1.

\section{Step 1}

Design the quantitative strand: [1] determine the quantitative approach [2] identify the samples [3] collect close-ended data with instruments [4] analyze quantitative data

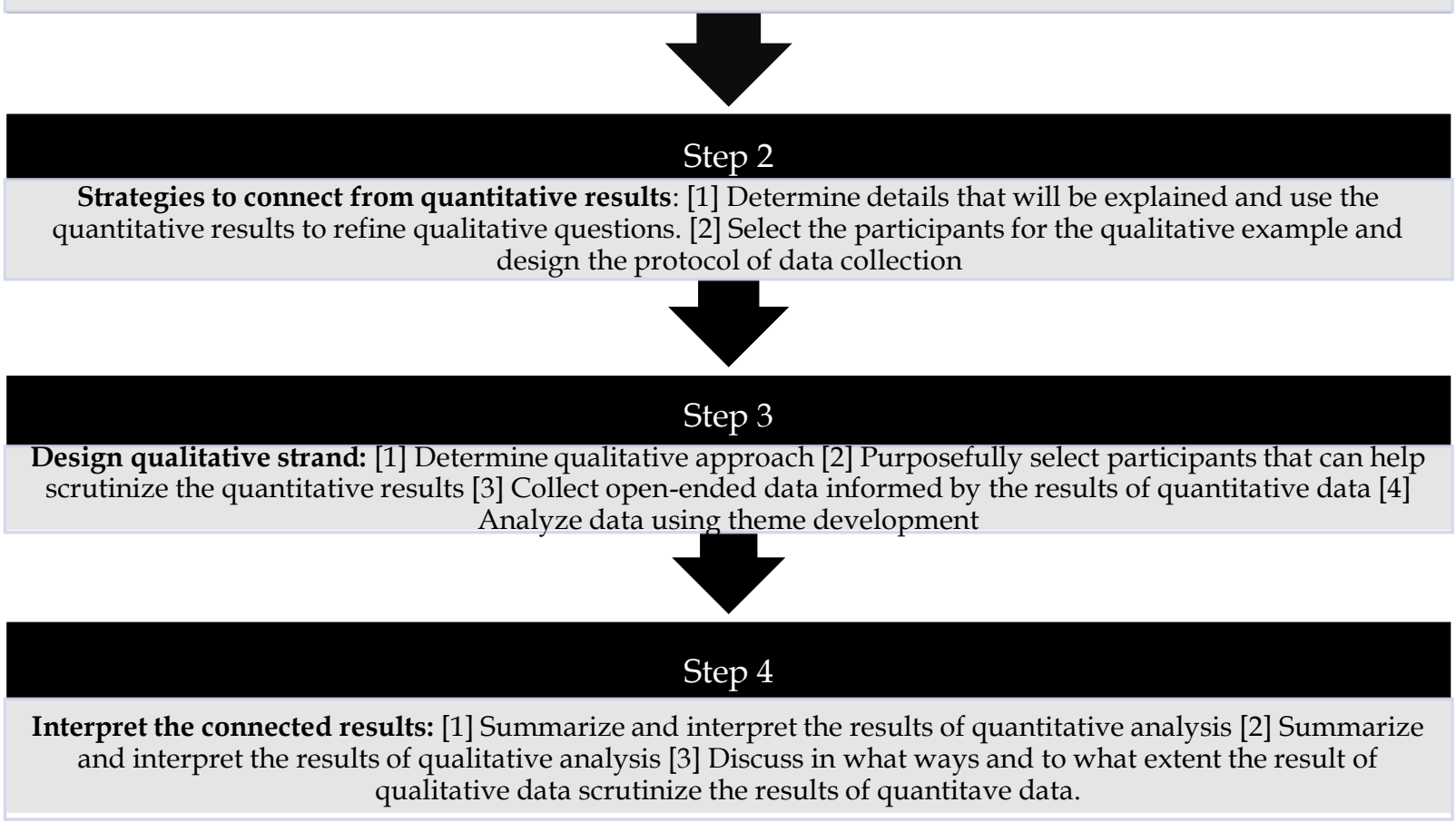

Figure 1. Process of explanatory sequential mixed method design.

\section{Participants}

The research participants were senior high school teachers and students in Indonesia who participated in online learning during the COVID-19 pandemic. After publicly announcing the survey to the researchers' professional networks, 136 teacher respondents and 107 student respondents of senior high schools agreed to participate in the survey and answer the questionnaires. The researchers purposefully chose the participants for the semi-structured interview. Two teachers and two students were selected to join the semi-structured interview, and all participants agreed to answer the interview questions. 


\section{Instrument and Procedures}

In conducting the survey, the questionnaire, created based on Roblyer \& Wiencke (2004) rubric, was sent to all researchers' networks in Indonesia. The teachers and students were also allowed to share the questionnaire with other students and teachers. The questionnaire link was also published publicly so that more participants could join. In the survey, to protect participants' privacy, the researchers did not ask for identities. In addition, to measure the reliability and validity of the questionnaire, the researchers measured the questionnaire's interrater reliability and correlation of each item with the perception categories. For the interrater reliability, the teachers' and students' questionnaires Cronbach a coefficient were 0.85 and 0.71 respectively which meant that the interrater reliability score was high. Additionally, based on the correlation analysis measurement, the results showed that each item in teachers' and students' questionnaire were significantly correlated with the perception categories in the rubric. The score for each item for teachers' survey were $0.76,0.81,0.74,0.78,0.80$. Further, the students' questionnaire correlation analysis results were $0.72,0.70,0.70,0.64,0.65$. The measurement results showed that the questionnaires were reliable and valid, and this was consistent with the previous study's measurement, which measured the validity and the reliability of the questionnaire (Roblyer \& Wiencke, 2004).

Related to the semi-structured interview, the researchers chose and invited two teachers and two students who filled the survey earlier. The interview was conducted in two strategies. The first strategy was using online meetings. It was because the participants lived far from the researchers. Further, a face-to-face interview was also conducted. The researchers conducted the face-to-face interview after we got an agreement from the participants, and we also strictly followed health protocol to ensure that everyone was healthy. Then, all interview recordings were saved in Google Drive on a protected laptop.

\section{Data Analysis}

To analyze the data, the researchers reviewed the data from surveys and interviews proposed by Creswell \& Clark (2017). For survey data, the data were statistically analyzed using Microsoft Excel to grasp a better picture of teachers' and students' perceptions and compare perceptions between these two groups. Firstly, to calculate the data, the data was turned into numbers so that the calculation could proceed. Then, each student's or teacher's response was calculated to get the final scores. These final scores were converted into perceptions' categories based on Roblyer \& Wiencke (2004) rubric. Additionally, the researchers also calculated the perceptions of each interaction's aspect. The average score of each element was counted to understand teachers' and students' perceptions on each interaction aspect.

Furthermore, for interview data, the interviews were transcribed first. Then, the transcript was analyzed by using thematic analysis. Thus, the data was coded based on specific categories, and then it was categorized following the rubric themes. It was because the goal of the interview was to refine the complete picture for each category from the questionnaires. Then, the results were examined and connected to the rubrics and literature. 


\section{RESULTS AND DISCUSSION}

\section{Survey's Results}

To better understand teachers' perceptions of their interactions in online classrooms, the researchers examined the data from 136 teachers from all locations in Indonesia. Based on the data analysis, more than half of the respondents believe that their interactions are high. They think that they perform well in interacting with students and content knowledge. Interestingly, 11 teachers believe that their interaction quality is astonishing, so that they claim a perfect score for each online learning interaction aspect measured in the questionnaire. Additionally, some teachers believe that their interaction quality is moderate, and only a few teachers believe that their interaction's performance is not adequate. To better understand the explanation above, a detailed picture of teachers' perceptions can be seen in Table 1 .

Table 1. Summary of teachers' perceptions of interactions quality in online classrooms.

\begin{tabular}{lcc}
\hline Interaction quality perceptions & Teacher respondents & Percentage \\
\hline High (overall score between18-25) & 83 & $61,03 \%$ \\
Moderate (overall score between 10-17) & 47 & $34,56 \%$ \\
Low (overall score between 1-9) & 6 & $4,41 \%$ \\
\hline
\end{tabular}

Nevertheless, based on the calculation of each interaction element in an online classroom, the data shows that, on average, teachers do not perform high-quality interactions. Teachers believe that they perform moderate quality of interaction regarding social building interaction, instructional design interaction, learners' and teachers' engagement, in addition. Unlike these four elements, Indonesian teachers in senior high school believe that their interactions with technology are above average. Thus, many teachers gave a high score for this element. These results can be seen in the Table below (Table 2).

Table 2. Descriptive statistics of Interactions in the online classroom (teachers)

\begin{tabular}{|c|c|c|c|c|c|c|}
\hline $\begin{array}{l}\text { Interaction's } \\
\text { elements }\end{array}$ & $\begin{array}{l}\text { Minimum } \\
\text { score }\end{array}$ & $\begin{array}{l}\text { Maximum } \\
\text { score }\end{array}$ & $\begin{array}{l}\text { Scale } \\
\text { range }\end{array}$ & Mean & $\begin{array}{l}\text { Standard } \\
\text { deviation }\end{array}$ & Description \\
\hline $\begin{array}{l}\text { Social building } \\
\text { interaction }\end{array}$ & 1 & 5 & $1-5$ & 3,85 & 1,31 & $\begin{array}{l}\text { Moderate } \\
\text { interaction }\end{array}$ \\
\hline $\begin{array}{l}\text { Instructional design } \\
\text { interaction }\end{array}$ & 1 & 5 & $1-5$ & 3,56 & 1,26 & $\begin{array}{l}\text { Moderate } \\
\text { interaction }\end{array}$ \\
\hline $\begin{array}{l}\text { Technology } \\
\text { resources } \\
\text { interactivity }\end{array}$ & 1 & 5 & $1-5$ & 4,21 & 1,12 & $\begin{array}{c}\text { Above average } \\
\text { interaction }\end{array}$ \\
\hline $\begin{array}{l}\text { Students' } \\
\text { engagement }\end{array}$ & 1 & 5 & $1-5$ & 3,09 & 1,20 & $\begin{array}{l}\text { Moderate } \\
\text { interaction }\end{array}$ \\
\hline $\begin{array}{l}\text { Teachers' } \\
\text { engagement }\end{array}$ & 1 & 5 & $1-5$ & 3,65 & 1,28 & $\begin{array}{l}\text { Moderate } \\
\text { interaction }\end{array}$ \\
\hline
\end{tabular}

Based on the summary data of students' perceptions, the data differs from the teachers. In other words, students have different perceptions of the interaction quality in online classrooms. For instance, the students who claim that the interaction has high quality do not reach 50 percent. To be precise, it is 46 percent of students believe that the interaction quality is high. This result is almost similar to the students who think that the interaction quality is moderate. The data shows that 48 percent of student respondents believe that the learning interaction is moderate. Only a few students 
Teachers' and Students' Perceptions of Online Learning Interactions amidst the COVID-19 Pandemic in Indonesian Senior High Schools

believe that the interaction quality is low $(4,67 \%)$. Detailed information can be seen in Table 3.

Table 3. Summary of students' perceptions of interactions quality in online classrooms.

\begin{tabular}{lcl}
\hline Interaction quality perceptions & Student respondents & Percentage \\
\hline High (overall score between18-25) & 50 & $46,73 \%$ \\
Moderate (overall score between 10-17) & 52 & $48,60 \%$ \\
Low (overall score between 1-9) & 5 & $4,67 \%$ \\
\hline
\end{tabular}

However, the results show a different perspective when the data is analyzed based on each interaction aspect. The students considered two aspects of minimum quality: instructional design and students' engagement in an online classroom. It shows that students believe that teachers do not perform well in these two interaction aspects. Further, for the three other elements, students believe that, on average, teachers' interaction quality is moderate. Based on the data, the average score of social building interaction, technology interactivity, and teachers' engagement is three. A detailed explanation can be seen in Table 4.

Table 4. Descriptive statistics of Interactions in the online classroom (students).

\begin{tabular}{|c|c|c|c|c|c|c|}
\hline $\begin{array}{l}\text { Interaction's } \\
\text { elements }\end{array}$ & $\begin{array}{l}\text { Minimum } \\
\text { score }\end{array}$ & $\begin{array}{l}\text { Maximum } \\
\text { score }\end{array}$ & $\begin{array}{l}\text { Scale } \\
\text { Range }\end{array}$ & Mean & $\begin{array}{l}\text { Standard } \\
\text { deviation }\end{array}$ & Description \\
\hline $\begin{array}{l}\text { Social building } \\
\text { interaction }\end{array}$ & 1 & 5 & $1-5$ & 3,41 & 1,58 & $\begin{array}{l}\text { Moderate } \\
\text { interaction }\end{array}$ \\
\hline $\begin{array}{l}\text { Instructional } \\
\text { design interaction }\end{array}$ & 1 & 5 & $1-5$ & 2,94 & 1,3 & $\begin{array}{l}\text { Minimum } \\
\text { Interaction }\end{array}$ \\
\hline $\begin{array}{l}\text { Technology } \\
\text { resources } \\
\text { interactivity }\end{array}$ & 1 & 5 & $1-5$ & 3,96 & 1,2 & $\begin{array}{l}\text { Moderate } \\
\text { interaction }\end{array}$ \\
\hline $\begin{array}{l}\text { Students' } \\
\text { engagement }\end{array}$ & 1 & 5 & $1-5$ & 2,98 & 1,2 & $\begin{array}{l}\text { Minimum } \\
\text { Interaction }\end{array}$ \\
\hline $\begin{array}{l}\text { Teachers' } \\
\text { engagement }\end{array}$ & 1 & 5 & $1-5$ & 3,61 & 1,3 & $\begin{array}{l}\text { Moderate } \\
\text { interaction }\end{array}$ \\
\hline
\end{tabular}

\section{Interview Results}

The interview results explained in this section are created to investigate in detail related to five interaction elements discussed in the survey, namely social building interaction, instructional design interaction, technology interactivity, teachers' engagement, and students' engagement. The interview attempts to provide a bigger picture related to teachers' and students' interaction in the online learning environment by delivering voices from teachers and students.

\section{Social building interaction}

Regarding building a connection between teachers and students, teachers argued that they had done their best to be socially closer with the students based on the interview . Overall, the teachers acknowledged that they attempted many ways to communicate with the students. For instance, T1 stated that:

T1: "At the beginning of the lesson, [I] ask their condition. Then, I ask, because I also want to build their characters, what good deeds have you done today? Sometimes, I am also joking with the students. The students say something funny; I also want to answer their statements casually. Because I think online learning is stressful. That is the reason why when I talk [to students], I need to laugh." 
Like the first teacher, the second teacher believed that informal communication is essential to build connections and relationships with the students. To confirm this statement, T2 explained that:

T2: "I want to build the connection with the students by becoming their friends instead of becoming a teacher. It is because I put myself in their shoes. Thus, when they want to discuss something outside the learning materials, I try to give their time so that they [the students] do not feel any gap between teachers and students. I want my students to feel comfortable to talk about their problems with me."

Nevertheless, unfortunately, the students do not have the same perceptions as the teachers in this part. Students believe that teachers rarely build a social connection with them during online learning. Many teachers often directly teach the students without having a casual conversation or asking about their condition. S1 confirms this statement. S1 said that:

S1: "Usually, teachers ask sudden questions related to the materials before and after the learning. It is rare for teachers to approach the students socially. I think not all teachers implement this method [socially build their connection] in the online classroom."

The S2 statement backs up this S1 statement. He believed that teachers do not deliberately focus on building social interaction with the students. S2 explained this statement by saying:

S2: "In my opinion, to build a social connection with the students, teachers like to give the assignment to the students and to create group assignments. I think teachers rarely discuss something with students, especially old teachers. They [old teachers] even forbid students to discuss in an online classroom."

The result of the interview for social interaction is fascinating. From teachers' and students' perceptions, it appears that teachers and students neglect each other. Based on teachers, they admit that they do their best to build their connection with students. Many ways are tried to ensure that teachers could be close with students. However, students negate their statements. Many teachers, especially the old ones, ignore building the connection with students. According to their reports, even some teachers do not allow students to discuss something in the online classrooms.

\section{Instructional Design Interaction}

To build interaction for teaching, teachers admit that it is hard to teach in an online setting. Some problems, such as internet access, can hinder communication with the students. For example, T1 admitted that she rarely explains the materials to the students. She often directs the students to access the LMS due to her considerations on internet access. Further, she explained that:

T1: "Imagine. All learning activities are conducted via zoom. However, I prefer to conduct the learning via WhatsApp. After I ask my students about their conditions and activities in WhatsApp, I tell them, "I already share the assignments in Google Classroom." [I said that] because our LMS is Google Classroom. So, I do not use Zoom or Google meet [online conference] at all. Thus, our interactions are only in the form of written communication. It is because not all students can have an internet quota for Zoom." 
Nevertheless, a unique perspective was uttered by the second teacher participant. T2 stated that he always tried to create learning which focuses on students' and teachers' interactions. He wanted to say that his online classroom is full of interactions among students. On the other hand, he also added information that some of his colleague teachers did the opposite. Some teachers only focus on their explanation about the learning but not on the students' interaction. T2 stated that:

T2: "For me, I want to encourage students to interact with each other because there is no face-to-face interaction. I want that my online class could be more alive with interaction. But, from what I know from my colleagues, some teachers only explain the materials. Some also encourage interaction in the online classroom."

Again, from the students' perspective, students had different perceptions of learning interactions in online learning settings. Students believed that teachers only like to explain and share assignments rather than communicate with the students, especially the senior teachers. S1 confirmed this by stating:

S1: "In my opinion, teachers only like to explain the materials rather than to encourage students to discuss in the online classroom, especially the senior teachers. I think their goal is only to explain the learning materials. The only interaction with teachers is usually when [we] submit our assignments."

Not only S1 who believed this perspective, but S2 also confirmed S1 answers. According to S2, teachers only focus on delivering the materials rather than building some communication with students. S2 said:

S2: "To me, teachers tend to explain the material rather than interact with students. But, I think some teachers want to interact with students by asking students some questions when teaching the learning materials. On the other hand, some others only focus on explaining, explaining, and explaining the materials."

The exciting part of students' and teachers' statements is the similarities of the perceptions. Both sides acknowledge that some teachers provide opportunities for students to have interaction in the online classroom. However, some teachers only focus on their explanation and ignore students' participation in the learning process. This demonstrates that not all teachers in Indonesia give students access to be involved in the learning process via an online learning platform.

\section{Technology Interactivity}

The third interaction element is related to the use of technology. Teachers argued that they tried to maximize the interactions through technology. In the learning activities, sometimes the technology they use focused on one-way communication. Sometimes, they also argue that teachers encourage two-way communications through technology. In detail, T1 explained:

T1: "[I admit that] sometimes it supports one-way communication, and sometimes it supports two-way communication. [To support two-way communication] I usually use WhatsApp before joining zoom or Google Classroom. I cannot leave WhatsApp. For instance, [I said to my students] "I want to share the materials Google Classroom". It means I need to use WhatsApp first [to inform the students]. I also check my students' attendance or checking students' readiness through WhatsApp." 
Confirming the T1 statement, T2 also admitted that the interaction through technology is sometimes one-way communication. Although, he also argued that he did not lose any opportunities from other students to build contact with him. Specifically, T2 said:

T2: "For me, I usually use WhatsApp to share the materials with the students. I also send the materials through an online conference platform. I admit that I often utilize one-way communication for delivering the learning materials in the online classroom. Nevertheless, I do not close any opportunities for my students to ask in detail about the materials that I share online."

In this interaction element, teachers and students have similar answers. Students confirmed the teachers' statements which convey that the materials were usually shared through WhatsApp. Students also acknowledged that teachers often create learning materials that encourage one-way communication rather than two-way communication. For instance, S1 said:

S1: "Usually, teachers share the learning materials through WhatsApp group, and it is in the form of PowerPoint. The files are shared on time according to the schedule. However, some teachers design materials that encourage two-way communication between teachers and students. On average, the materials do not facilitate two-way communication.

Supporting the first student's statement, S2 said that teachers tend to share the learning materials in the WhatsApp group. He also added that the learning materials do not support two-way communication. In detail, he explained:

S2: Teachers often share the materials through WhatsApp group; sometimes, the teachers share the materials through Google Meet. So, when we had the Google Meet session after the teachers explained the materials, some students asked for the PowerPoint files. Then, the teachers gave the file to the students. Further, I think the materials shared never encourage the students to have two-way communication.

Based on the interview, it appears that teachers often share all learning materials through social media, especially WhatsApp. It is rare for teachers to share the materials through LMS. It is probably because it is easier for both teachers and students to access social media than LMS. Further, in the interview, teachers, and students admit that the learning materials do not encourage two-way communication with teachers. The learning materials often only focus on explaining the knowledge rather than the interaction between teachers and students.

\section{Students' Engagement in Online Classrooms}

When the students join an online classroom, teachers believe that students are not sufficiently engaging with the learning. According to the teachers' participants, many students passively joined the learning and kept silent when the learning was conducted online. To better understand this, T1 explained:

T1: "I believe that the students answer the questions if it is in the form of assignments. If I have 4 students who want to answer my question, I think it is already very good. But, if the questions or answers during our online interaction, the answer is no. 50-70\% of students are usually not responsive in the online classroom. Additionally, if students respond to my question, they tend to answer it simply." 
Supporting the first teacher's statement, T2 also thought that students did not learn well. Many students did not answer his question when the online learning was conducted. In responding to this interaction element, T2 said:

T2: "In my experience, I think it is less than 50 \% of students who are active in my online classrooms. The possibility is only 3 or 4 students who are very responsive to answer my questions. It is 3 or 4 students out of 34 students who are involved in the learning. In my opinion, I classify three types of students. Firstly, the responsive students. It is about 10 percent of the total students. Secondly, [it is about] $50 \%$ of students who wait for teachers to call their name to the response. And the rest, [it is about] 40 percent of students who do not engage the learning at all."

Both students confirmed the teachers' arguments in this section. The students believe that the participation of students in online learning is low. Only a few students engage in the learning. For instance, $\mathrm{S1}$ explained:

S1: "Only 20 until 30 percent of students who respond to the questions asked by the teachers. For the rest of the students, I do not know. Usually, it is always the same students who answer the questions from the teachers. Others usually keep silent or leave the class, but the computer is still online. Further, in some classes, if the subject is important, students' response is complex. However, if the lesson is hard, the student's answer will be concise."

Based on students' and teachers' explanations, it appears that students do not actively engage with the teachers making the interaction disappear from the online classroom. Only a few students respond to the question or initiate the conversation between teachers and students. Further, we could see that the harder the subject is, the less interaction will be created. Thus, teachers need to create bigger efforts so that students can be more active in online classrooms.

\section{Teachers' Engagement in The Online Classroom}

Overall, teachers argued that they tried to answer all students' questions below 24 hours. They said that because they want to emphasize and strengthen their engagement with students in online classrooms. Teachers also admitted that they are open for consultation outside the learning hours. Further, in answering the questions from students, teachers also tried to explain the answer in detail. Thus, students understand the materials comprehensively. For instance, T1 said:

T1: For me, I already told my students that I would respond to your questions in 24 hours. If you have any questions, you can chat with me at any time, but I cannot promise to answer them directly. I only promise to answer the questions within 24 hours. Further, I think that I will try to answer their question in detail. However, it depends on the students and questions. If the answer to the questions is simple, I will simply answer the questions. But, if the questions are complex, the answer will be complex."

Similar to this response, T2 said that he attempted to reply to all students' questions in one day. Additionally, he also tried to give complex feedback for the questions that needed elaborate explanations. In detail, T2 said: 
T2: "I can promise my students to answer the questions directly. If the students ask outside the learning hours, I will answer their questions from 7 until 10 p.m. Further, if the students ask essay questions, I will give complex feedback to the students. If the topic is trivial, I will give questions back to the students to think first. When they could not answer my questions, then I will directly show them the answer."

The students' responses seem to agree with the teachers' statement related to teachers' engagement in the classroom. Students admitted that teachers answer students' questions only in a day or less than that. However, students argued that not all teachers give complex feedback to the students' questions. Some teachers only like to provide simple feedback rather than complex ones. For example, here is what $\mathrm{S} 1$ said:

S1: "When I ask my teachers through WhatsApp, they usually answer the questions, maximum, in a day. But they usually are fast responses. Related to the complexity of the feedback, some teachers give simple feedback, and some give me complex feedback. A simple feedback response example is that teachers usually tell us to reread the materials in Google."

The second student participant also confirmed the first students' answers. He thought that some teachers give complex and coherent feedback to understand the materials they had asked for earlier. For example, S2 stated:

S2: "Some teachers give a very complex and coherent feedback until we understand. When we ask questions, the teachers' explanation makes us feel like, "aha," we understand the materials."

\section{Discussion}

The survey and the interview results have shed light on the research question, which investigates teachers' and students' perceptions of online learning. The data above shows that teachers claim that the interaction in online learning is good. More than 60 percent of teachers score high for their online teaching practice. It is similar to the finding of Yang (2020) in China. Collecting data from more than 15000 teachers, the researcher found that online interaction could improve mutual understanding between students and teachers. It demonstrates that teachers tend to perceive online learning positively. According to teachers, interaction within online settings would enhance the connection between students and teachers.

Unlike teachers' perceptions, based on the survey, students tend to perceive the interaction as less effective than the teachers. It can be seen from the data, which states that fewer students believe that the learning interaction is high. The majority of students claim that the learning interaction is moderate. Unsurprisingly, this is not only the case that the teachers face around the globe. In some countries, many students consider online learning is less efficient and full of learning challenges (Almahasees et al., 2021; Syauqi et al., 2020). For instance, high school students in Turkey also feel that online learning is not effective. They argue that teachers lack educational conversation when they teach in online classrooms (Aydin et al., 2015). More studies also prove that students might feel reluctant to join online classrooms, so they negatively perceive the online learning experience (Imsa-ard, 2020; Surani \& Hamidah, 2020).

According to Cranfield et al. (2021), the negative results of students' perceptions are caused by teachers' failure to fulfill the students' needs. To achieve the students' needs, 
Teachers should identify students' minimum digital requirements in online learning, i.e., online learning supports and online learning facilities (Cranfield et al., 2021). When this requirement is fulfilled, students might have positive perceptions of online learning. For instance, in the study conducted by Burns (2013), students perceive that online learning is convenient even when online learning is compared to face-to-face learning. As a result, students feel the need to have extra online classes for education (Burns, 2013).

Regarding the five interaction elements being studied, teachers' engagement and social building interactions are perceived the same by students and teachers. Both parties give a moderate score for the exchange. In the teachers' engagement aspect, teachers and students provide the same answer as to why they choose to deliver the moderate score. Both argue that teachers effectively engage with the students in online learning. Interestingly, although the score is similar in the social building interaction aspect, the explanation is different. Teachers argue that their social interaction caters to students' problems. They claim that they could build a connection with students quickly. However, from the students' side, it is not valid. Many teachers cannot make a social connection with students through interaction, especially the senior teachers. Students argue that teachers only focus on giving students some explanations and assignments rather than approaching students personally. This issue should be considered seriously. Teachers should improve their online pedagogy performance so that the learning could be more useful (Cheok et al., 2017).

For instructional design interaction, technology interactivity, and students' engagement, teachers and students do not share the same view. Instructional design interaction, for example, students claim the minimum quality of interaction. This is different from teachers' perceptions which claim that their instructional interaction is moderate. In detail, students argue that teachers only focus on explaining in one-way communication. The exchange does not go in two-way communication; students cannot effectively engage the learning.

Additionally, students provide a unique fact related to instructional design interaction. That senior teachers tend to focus on explaining materials rather than having a discussion with students. They even forbid students to discuss in the online classroom. It might be the possibility that students give a minimum score for this interaction aspect. Teachers might not have decent instructional design interaction because they are not ready to conduct distance learning (Jalal, 2020). Jalal (2020) argues that many teachers are not prepared with online education pedagogy. As a result, this might cause minimum interaction in the online classroom.

Students and teachers do not share the same view regarding technology interactivity because students think that teachers do not encourage two-way communication materials. On the other hand, teachers believe that they already give their best shot to design two-way communication learning materials to maximize the interaction. Although teachers admit that they have designed better communication through technology, students still feel that communication in the online classroom is a one-way interaction. This finding is similar to the study of Masrizal et al. (2020). Students often think that the communication in the online classroom is not responsive. Instructors usually do not provide sufficient response to the students' interaction. It means that teachers need to improve their communication style to better interact with the teachers through online platforms. 
The final interaction aspect studied in this research is students' engagement. The finding shows an interesting fact. It is students tend to admit that their engagement is minimum in the classroom. The teachers themselves confirm this fact, although they score higher for students' engagement. Students acknowledge that only a few students attempt to engage with the learning activities in the online classrooms. Interestingly, others like to disengage the learning by turning off their camera and microphone during the learning process. This finding demands teachers to be more creative so that the engagement rate can be higher. Kahn et al. (2017) suggest that teachers can practice the exercise of reflexivity to the students. It is the way to make the students aware of their priority and relate it to their social context. In other words, teachers need to make the students realize their goal of learning in online settings. It might be possible if teachers enhance their social communication with students.

\section{CONCLUSIONS}

Researchers have shown that teachers and students have different perspectives on online learning. In this study, teachers are more positive in considering online learning compared to the students. Various aspects cause this other point of view. The most significant elements which influence the perceptions are the instructional design, technology, and social interactions. It can be suggested that, although the learning has been conducted for more than one year, many challenges to Indonesian online learning exist. Teachers may need a more creative teaching approach so that online learning could be as effective as face-to-face learning. Further, based on the discussion section above, there are several ways to improve the online learning experience. Firstly, teachers may need to be aware of students' digital requirements. It means that teachers need to analyze students' needs when they join online classrooms, such as considering the learning facility and designing better distance education pedagogy. Secondly, better social interaction might be encouraged to get closer with the students. Only focusing on the explanation does not necessarily improve the learning experience. Students in this research suggest that they need better social interaction with the teachers. In other words, teachers' consideration of social interaction is required in order to enhance the quality of online learning. In extending this research, future researchers need to understand the limitation of this research. Future studies may compare the findings with the fundamental teaching practice in the online classroom. It is because the perceptions in this study are limited to students' and teachers' opinions outside the classroom without any comparison with the actual learning and teaching practice. Future research needs to delve into this comparison the fundamental problems of online learning can be deeply identified.

\section{ACKNOWLEDGEMENTS}

We would like to convey our gratitude to Universitas Dinamika. Without their funding, we would not be able to conduct this research. This research was funded under the scheme 'Penelitian Dosen Pemula' (PDP), with contract number: 006/ST$\mathrm{PPM} / \mathrm{KPJ} / \mathrm{VII} / 2021$. Additionally, our highest gratitude is also for teachers or students who are actively involved in our research and share their beautiful insights for this research. 
Teachers' and Students' Perceptions of Online Learning Interactions amidst the COVID-19 Pandemic in Indonesian Senior High Schools

\section{REFERENCES}

Absor, N. F. (2020). Pembelajaran sejarah abad 21: Tantangan dan peluang dalam menghadapi pandemi covid-19. Chronologia: Journal of History Education, 2(1), 30-35. https://doi.org/10.22236/jhe.v2i1.5502

Al-Busaidi, K. A. (2012). Learners' perspective on critical factors to LMS success in blended learning: An empirical investigation. Communications of the Association for Information Systems, 30(1), 11-34 .https:// doi.org/10.17705/1CAIS.03002

Ally, M. (2004). Foundations of educational theory for online learning. Athabasca University.

Almahasees, Z., Mohsen, K., \& Amin, M. O. (2021). Faculty's and students' perceptions of online learning during covid-19. Frontiers in Education, 6(1), 1-10. https://doi.org/10.3389/feduc.2021.638470

Anderson, T. (2004). Toward a theory of online learning. In T. A. F. Elloumi (Eds.), Theory and practice of online learning (2nd ed., 342-367). Athabasca.

Annur, M. F., \& Hermansyah. (2020). Analisis kesulitan mahasiswa pendidikan matematika dalam pembelajaran daring pada masa pandemi covid-19. Jurnal Kajian, Penelitian, dan Pengembangan Kependidikan, 11(2), 195-201. https:// doi.org/10.31764

Aydin, S., Akkan, Y., Arpaz, E., \& Koparand, B. (2015). Online learning in vocational school: focus on students' perceptions. Procedia - Social and Behavioral Sciences, 174(1), 3663-3667. https:// doi.org/10.1016/j.sbspro.2015.01.1087

Baber, H. (2020). Determinants of students' perceived learning outcome and satisfaction in online learning during the pandemic of covid-19. Journal of Education and E-Learning, 7(3), 285-292.

Baber, H. (2020). Social interaction and effectiveness of the online learning - A moderating role of maintaining social distance during the pandemic covid-19. Asian Education and Development Studies, 1(1), 1-16. https:/ / doi.org/10.1108/AEDS-09-2020-0209

Boling, E. C., Hough, M., Krinsky, H., Saleem, H., \& Stevens, M. (2012). Cutting the distance in distance education: Perspectives on what promotes positive, online learning experiences. Internet and Higher Education, 15(2), 118-126. https:/ / doi.org/10.1016/j.iheduc.2011.11.006

Burns, B. A. (2013). Students' perceptions of online courses in a graduate adolescence education program. MERLOT Journal of Online Learning and Teaching, 9(1), 13-25.

Chakraborty, P., Mittal, P., Gupta, M. s., Yadav, S., \& Aora, A. (2020). Opinion of students on online education during the covid-19 pandemic. Human Behaviour and Emerging Technology, 3(3), 357-365. https://doi.org/10.1002/hbe2.240

Cheok, M. L., Wong, S. L., Ayub, A. F., \& Mahmud, R. (2017). Teachers' perceptions of elearning in Malaysian secondary schools. Malaysian Online Journal of Educational Technology, 5(2), 20-33. www.mojet.net

Cranfield, D. J., Tick, A., Venter, I. M., Blignaut, R. J., \& Renaud, K. (2021). Higher education students' perceptions of online learning during covid-19 a comparative study. Education Sciences, 11(8), 403-411. https:// doi.org/10.3390/educsci11080403

Creswell, J. W., \& Clark, V. L. P. (2017). Designing and conducting mixed methods research. SAGE Publlications, Inc.

Eom, S. B., \& Ashill, N. (2016). The determinants of students' perceived learning outcomes and satisfaction in university online education: An update. Journal of Innovative Education, 14(2), 185-215. https://doi.org/10.1111/dsji.12097

Garrison, D. R. (2009). Communities of inquiry in online learning. In L. Rogers (Eds.), Encyclopedia of distance learning (2nd ed., 352-355). IGI Global.

Garrison, D. R., Anderson, T., \& Archer, W. (2010). The first decade of the community of inquiry framework: A retrospective. Internet and Higher Education., 13(1-2), 5-9. https://doi.org/10.1016/j.iheduc.2009.10.003

Handarini, O. I., \& Wulandari, S. S. (2020). Pembelajaran daring sebagai upaya study from home (SFH) selama pandemi covid 19. Jurnal Pendidikan Administrasi Perkantoran (JPAP), $8(3), 496-503$. 
Teachers' and Students' Perceptions of Online Learning Interactions amidst the COVID-19 Pandemic in Indonesian Senior High Schools

Harris, H. S., \& Greer, M. (2017). Over, under, or through: Design strategies to supplement the LMS and enhance interaction in online writing courses. Communication Design Quarterly Review, 4(4), 46-54.

Horzum, M. B. (2015). Interaction, structure, social presence, and satisfaction in online learning. Eurasia Journal of Mathematics, Science $\mathcal{E}$ Technology Education, 11(3), 505-512. https://doi.org/10.12973/eurasia.2014.1324a

Imsa-ard, P. (2020). Thai university students' perceptions towards the abrupt transition to "forced" online learning in the covid-19 situation. Journal of Education Khon Kaen University, 43(3), 30-34.

Jalal, S. (2020). Kesiapan guru menghadapi pembelajaran jarak jauh di masa covid-19. Smart Kids: Jurnal Pendidikan Islam Anak Usia Dini, 2(1), 35-40. https:// doi.org/10.30631/smartkids.v2i1.61

Jamilah. (2020). Guru profesional di era new normal: Review peluang dan tantangan dalam pembelajaran daring. Premiere Educandum: Jurnal Pendidikan Dasar dan Pembelajaran, 10(2), 238-247. https://doi.org/10.25273/pe.v10i2.7494

Kahn, P., Everington, L., Kelm, K., Reid, I., \& Watkins, F. (2017). Understanding student engagement in online learning environments: the role of reflexivity. Education Technology Research Development, 65(1), 203-218. https:// doi.org/10.1007/s11423-016-9484-z

Korkmaz, G., \& Toraman, Ç. (2020). Are we ready for the post-covid-19 educational practice? An investigation into what educators think as to online learning. International Journal of Technology in Education and Science, 4(4), 293-309.

Kurniawan, G. F. (2020). Problematika pembelajaran sejarah dengan sistem daring. Diakronika, 20(2), 76-87. https://doi.org/10.24036/diakronika/vol20-iss2/148

Lasfeto, D. B., \& Ulfa, S. (2020). The relationship between self-directed learning and students' social interaction in the online learning environment. Journal of E-Learning and Knowledge Society, 16(2), 34-41. https://doi.org/10.20368/1971-8829/ 1135078

Masrizal, Fata, I. A., \& Erdiana, N. (2020). Investigating in-service teachers' perceptions on online and autonomous learning. Humanities and Social Sciences Reviews, 8(3), 456-465. https://doi.org/10.18510/hssr.2020.8349

Mehall, S. (2020). Purposeful interpersonal interaction in online learning: What is it and how is it measured? Online Learning Journal, 24(1), 182-204.

Murray, M., Perez, J., Geist, D., \& Hedrick, A. (2012). Student interaction with online course content: Build it and they might come. Journal of Information Technology Education: Research, 11(1), 125-140.

Northrup, P., Lee, R., \& Burgess, V. (2002). Learner perceptions of online interaction. Conference on Educational Multimedia, Hypermedia \& Telecommunications, 1(1), 1-7.

Rigianti, H. A. (2020). Kendala pembelajaran daring guru sekolah dasar di kabupaten Banjarnegara [Elementary schools' teachers online learning challenges in Banjarnegara regency] Elementary School, 7(2), 297-302.

Roblyer, M. D., \& Wiencke, W. R. (2003). Design and use of a rubric to assess and encoourage interactive qualities in distance courses. The American Journal of Distance Education, 17(2), 77-98. https://doi.org/10.1207/S15389286AJDE1702_2

Roblyer, M. D., \& Wiencke, W. R. (2004). Exploring the interaction equation: Validating a rubric to assess and encourage interaction in distance courses. Journal of Asynchronous Learning Networks, 8(4), 24-37.

Surani, D., \& Hamidah. (2020). Students' perceptions in online learning during the COVID-19 pandemic. IJoASER (International Journal on Advanced Science, Education, and Religion), 3(3), 83-95. https:// doi.org/10.33648/ijoaser.v3i3

Syauqi, K., Munadi, S., \& Triyono, M. B. (2020). Students' perceotions toward vocational education on online learning during the COVID-19 pandemic. International Journal of Evaluation and Research in Education, 9(4), 881-886. https://doi.org/10.11591/ijere.v9i4.20766 
Teachers' and Students' Perceptions of Online Learning Interactions amidst the COVID-19 Pandemic in Indonesian Senior High Schools

Wicks, D., Craft, B. B., Lee, D., Lumpe, A., Henrikson, R., Baliram, N., Bian, X., Mehlberg, S., \& Wicks, K. (2015). An evaluation of low versus high collaboration in online learning. Online Learning Journal, 19(4), 1-21. http:/ / doi.org/10.24059/olj.v19i4.552

Widiyono, A. (2020). Efektifitas perkuliahan daring (online) pada mahasiswa PGSD di saat $\begin{array}{lllll}\text { pandemi covid-19. Jurnal } & \text { Pendidikan, }\end{array}$ https:// doi.org/10.36232/ pendidikan.v8i2.458

Wuladari, M. A., Arga, H. S. P., Kelana, J. B., Herdiana, D., Altaftazani, \& Ruqoyyah, S. (2020). Analisis pembelajaran daring pada guru sekolah dasar di era covid-19. Jurnal Ilmiah UPT P2M STKIP Siliwangi, 7(2), 164-168.

Xhaferi, B., \& Xhaferi, G. (2020). Online learning benefits and challenges during the covid-19 pandemic - Students' perspective from SEEU. SEEU Review, 15(1), 86-103. https:// doi.org/10.2478/seeur-2020-0006

Yang, X. (2020). Teachers' perceptions of large-scale online teaching as an epidemic prevention and control strategy in China. ECNU Review of Education, 3(4), 739-744. https:// doi.org/10.1177/2096531120922244

York, C. S., \& Richardson, J. C. (2012). Interpersonal interaction in online learning: Experienced online instructors' perceptions of influencing factors. Journal of Asynchronous Learning Networks, 16(4), 83-98.

\footnotetext{
${ }^{*}$ Angen Yudho Kisworo, M. Tesol. (Corresponding Author)

Faculty of Economy and Business

Universitas Dinamika, Surabaya

Jl. Kedung Baruk 98, Surabaya

Email: angen@dinamika.ac.id
}

Oktaviani, S.E., M.M.

Faculty of Economy and Business

Universitas Dinamika, Surabaya

Jl. Kedung Baruk 98, Surabaya

Email: okta@dinamika.ac.id 